\title{
CDX2, COX2 and MUC2 Expressions in Barrett's Esophagus: Can They Be Useful in Determination of the Dysplasia?
}

\author{
Barrett Özofagusunda CDX2, COX2 ve MUC2 Ekspresyonu: \\ Displazinin Belirlenmesinde Yardımcı Olabilir mi?
}

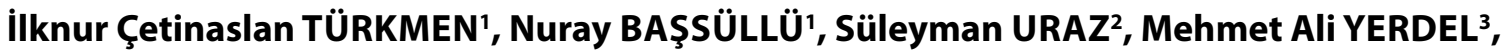 \\ Reşat MEMişOĞLU², Gülen BÜLBÜL DOĞUSOY²
}

'Department of Pathology, Istanbul Bilim University, Faculty of Medicine, ISTANBUL, TURKEY, ${ }^{2}$ Department of Pathology and Gastroenterology, Florence Nightingale Hospital, ISTANBUL, TURKEY, ${ }^{3}$ Department of General Surgery, Istanbul Surgery Hospital, iSTANBUL, TURKEY

\begin{abstract}
Objective: The description of Barrett's esophagus which is a risk factor for esophageal adenocarcinoma has differences, and the need of goblet cells for diagnosis is controversial. However, the pathophysiology in the metaplasia seen in Barrett's esophagus is not totally understood and new methods are searched for the assessment of progression to dysplasia. We aimed to search the immunohistochemical expression of CDX2, COX2 and MUC2 in Barrett's esophagus to detect any early evidence of intestinal metaplasia or dysplasia.

Material and Method: The staining properties were examined in the intestinal metaplastic (goblet cell-containing columnar epithelium), columnar (non-goblet columnar epithelium), distant columnar (non-goblet columnar epithelium distant from intestinal metaplastic epithelium) and squamous epithelium in 59 pathologically diagnosed Barrett's esophagus, 22 of which having dysplasia. The results were compared statistically with Pearson and Fisher exact tests.
\end{abstract}

Results: The distribution of the staining of intestinal metaplastic, non-goblet columnar distant columnar, and squamous epithelium, respectively were as follows: for CDX2 76.3\%, 23.7\%, 1.7\%, $0 \%$; for COX-2 93.2\%, 47.5\%, 8\%, 62.9\%; for MUC2 93.2\%, $11.9 \%, 4 \%$ and $0 \%$. The expression of CDX2, COX2 and MUC2 in the intestinal metaplastic epithelium was higher than the expression in distant and non-goblet columnar epithelium. The expression of CDX2, COX2 and MUC2 in the foci of dysplasia decreased significantly $(18.2 \%$, $27.3 \%, 31.9 \%$, and $\mathrm{p}=0.039,0.0001,0.0001$, respectively). COX2 expression in squamous epithelium was also lower when the adjacent mucosa has dysplasia $(\mathrm{p}=0.014)$.

Conclusion: The CDX2, COX2 and MUC2 expressions were seen in the intestinal epithelium having goblet cells. The use of the markers in the diagnosis is controversial but the difference in the Barrett esophagus-dysplasia sequence seems to be meaningful.

Key Words: Barrett esophagus, Immunology, Biopsy, Pathology, Immunohistochemistry, CDX2 protein, MUC2 protein, COX2 protein

(Turk Patoloji Derg 2012, 28:251-258)

Received : 05.06 .2012 Accepted : 13.08 .2012

\section{ÖZ}

Amaç: Özofagus adenokarsinomları için risk faktörü olan Barrett özofagusunun tanımı değişiklik göstermektedir ve tanı için goblet hücresinin olması gerekliliği tartışmalıdır. Ancak Barrett özofagusunda görülen metaplazinin patofizyolojisi tam olarak anlaşılmamıştır ve metaplazi-displazi geçişinin belirlenmesi için yeni yöntemler araştırılmaktadır. Çalışmamızda, Barrett özofagusunda immünohistokimyasal olarak CDX2, COX2 ve MUC2 ekspresyonu ve bunların intestinal metaplazi veya displazinin erken delili olup olamayacağını araştırmayı amaçladık.

Gereç ve Yöntem: Boyanma özellikleri, patolojik olarak Barrett özofagusu tanısı almış 22'sinde displazi izlenen 59 olguda, intestinal metaplazik (goblet hücresi içeren kolumnar epitel), goblet hücresi içermeyen (non-goblet) kolumnar epitel, uzak kolumnar epitel (intestinal metaplastik epitelin uzağındaki non-goblet kolumnar epitel) ve skuamöz epitelde ayrı ayrı değerlendirilmiştir. Sonuçlar istatistiksel olarak Pearson ve Fisher testleri ile karşılaştırılmıştır.

Bulgular: İntestinal metaplastik, non-goblet kolumnar, uzak kolumnar ve skuamöz epiteldeki boyanma dağılımları sırasıyla şöyleydi: CDX2 için \%76,3; \%23,7; \%2, \%0; COX-2 için \%93,2; \%47,5; $\% 8$; \%62,9 ve MUC2 için \%93,2; \%11,9; \%4; \%0. CDX2, COX2 ve MUC2 ekspresyonu intestinal metaplastik epitelde uzak yerleşimli ve non-goblet kolumnar epitel ile karşılaştırıldığında daha yüksek idi. Displazi odaklarındaki CDX2, COX2 ve MUC2 ekspresyonu istatistiksel olarak anlamlı şekilde azalmıştı (sırasıyla \%18,2, \%27,3, $\% 31,9$ ve $\mathrm{p}=0.039,0.0001,0.0001)$. Displazi varlığında, komşu skuamöz epitelde de COX2 ekspresyonu düşük olarak izlendi $(\mathrm{p}=0.014)$.

Sonuç: Goblet hücresi içeren intestinal tip epitelde CDX2, COX2 ve MUC2 ekspresyonu izlenmektedir. Bu belirteçlerin Barrett özofagusu tanısında kullanımı tartışmalı olmakla birlikte, Barrett özofagusu-displazi sekansındaki fark anlamlı görünmektedir.

Anahtar Sözcükler: Barrett özofagusu, Patoloji, Biyopsi, İmmunohistokimya, CDX2 protein, MUC2 protein, COX2 protein

Correspondence: İlknur Çetinaslan TÜRKMEN

Department of Pathology, İstanbul Bilim University, Faculty of Medicine, İSTANBUL, TURKEY

E-mail: ilknurcetinaslan@hotmail.com Phone: +90 2122884456 


\section{INTRODUCTION}

Barrett esophagus (BE) was defined previously as presence of any columnar epithelium (gastric, cardiac, oxyntic or intestinal) lining the distal esophagus. Although the necessity of metaplastic or intestinalized columnar epithelium with goblet cells (GC) for the histological diagnosis is widely accepted, it is still controversial. The reason for this approach is due to the early findings that dysplasia and carcinoma develop only in intestinal metaplasia (IM) areas (columnar epithelium with GC) (1). However, several weaknesses of this definition exist, such as; it is now well recognized that the background non-goblet columnar epithelium (columnar epithelium adjacent to IM without goblet cells), (NGCE) shows physiologic properties of 'intestinal' differentiation, such as expression of intestinal transcription factors like CDX2, MUC2, hepPar1, villin, and DAS-1 (2) and there is data to support that NGCE is also under the risk of progression to dysplasia (3) and studies are ongoing to find new markers for identification of NGCE.

Homeobox (HOX) genes are expressed in tissues and structures that arise from the ectoderm and mesoderm and among these genes CDX1 and CDX2 play role in the development of gut (4). The transformation of endoderm to columnar epithelium is achieved by the expression of CDXs $(4,5)$. CDX1 and CDX2 are also shown to regulate the expression of other intestinal-type genes such as sucrase-isomaltase, MUC2 and furin (4). In several studies of esophageal biopsy specimens taken from BE patients, CDX2 expression levels were higher in BE than in normal esophageal squamous epithelium (SE), in which thelevels are almost undetectable or higher levels of mRNA are detected in IM than cardiac and oxynto-cardiac epithelium (4-6). By immunohistochemistry, CDX2 has been demonstrated in $100 \%$ of $\mathrm{BE}$ with or without dysplasia, and esophageal adenocarcinoma (EA) (4). However, CDX2 is reported to be decreased in the presence of dysplasia (5). Colleypriest et al. has found CDX2 mRNA in $1 / 3$ of the BE patients in the SE, a result showing that CDX2 expression preceeds the phenotypic changes (7).

Mucins are high molecular weight glycoproteins synthesized by epithelial tissues and are coded by MUC genes. Mucins are subdivided into two groups broadly; the secreted ones that form extracellular gels (MUC2, MUC5AC, MUC5B and MUC6), and membrane bound mucins (MUC1, MUC3 and MUC4) (8-10). Immunohistochemical studies have shown that MUC2 is not expressed in normal esophageal SE but is commonly found in colonic and intestinal GC as well as the GC of BE mucosa (10-12) and decreased expression of MUC2 is correlated with the presence of dysplasia (9). Bile acids up-regulate both intestinal differentiation factor CDX2 and goblet cell-specific gene MUC2 in normal esophageal and cancer cell lines. Thus, bile acid-stimulated MUC2 up-regulation correlates directly with CDX2 upregulation (11).

The cyclooxygenase (COX) genes encode proteins that catalyze the synthesis of prostaglandin from arachidonic acid. There are 2 isoforms of COX: COX1 and COX2. COX1 is constitutively expressed in most tissues and COX2 is induced in response to inflammation (7). COX2 is not expressed in non-inflamed gastrointestinal epithelium but is expressed in esophagitis, $\mathrm{BE}$ and intestinal metaplasia of the stomach and increases in the spectrum from metaplasia to cancer $(7,13,14)$. Studies show that un-conjugated dihydroxy bile acids, chemodeoxycholic acid and deoxycholic acid are potent stimulators of COX2 induction in BE and EA cells $(7,15)$, and increase in COX2 results in increased cell proliferation, IM, dysplasia and EA (7).

In this study, our aim was to investigate the presence of CDX2, COX2 and MUC2 in BE in comparison with the NGCE, distant columnar epithelium (non-goblet columnar epithelium distant from intestinal metaplastic epithelium), (DCE), and SE, in order to detect any early evidence of IM, and also looked for the differences in their expression in the presence of dysplasia.

\section{MATERIAL and METHODS}

Case Selection: 59 archived paraffin embedded sections of the distal esophagus were chosen for the study. Our study group included biopsy proven endoscopic BE cases of any length. Pathologic diagnosis was given when columnar epithelium with GCs were seen in the biopsy specimen. The endoscopic biopsy specimens were collected over a twoyear period from 2008 to 2010. Ten cases of esophagitis and additional ten cases which were clinically thought to have $\mathrm{BE}$, but not showing intestinal metaplasia in biopsy material and therefore not diagnosed as BE pathologically were also included in the study as the control group. The cases with "indefinite for dysplasia" were not included.

Evaluation of dysplasia: Evaluation of dysplasia was done according to nuclear and architectural features. For low grade dysplasia, criteria were basally located, pencil shaped, elongated, enlarged, crowded, hyperchromatic nuclei, sometimes irregular contour with inconspicuous nucleoli. There should be mild loss of polarity. The diagnosis of high grade dysplasia was made by the presence of marked cytological abnormalities and/or significant architectural complexity of glands with marked nuclear pleomorphism, 
polarity loss, nuclear irregularity and increased nuclear/ cytoplasmic ratio as well as atypical mitosis especially at the upper levels of the crypts. In addition to initial evaluation, all cases were re-evaluated for dysplasia after immunohistochemical staining.

Immunohistochemistry: Paraffin embedded tissue sections were baked in an oven at $60^{\circ} \mathrm{C}$ for overnight and then deparaffinized through three changes of xylene and then rehydrated through a series of decreasing concentrations of ethanol solutions to distilled water. Epitope retrieval was performed by microwave cooking at $600 \mathrm{~W}$ for 20 minutes in $10 \mathrm{mM}$ citrate buffer, $\mathrm{pH} 6.0$ and then left to cool at room temperature for 20 minutes. Endogenous peroxidase activity was blocked in 3\% hydrogen peroxide in methanol for 5 minutes at room temperature and washed in phosphate buffered solution (PBS) for ten minutes. After blocking nonspecific antibody binding with UV block for 10 minutes, the slides were incubated with antibodies against COX2 (Ptgs2 polyclonal antibody; Catalog: PAB11630, dilution 1/80, Abnova, USA), CDX2 (polyclonal antibody; Clone: 09749, ready to use, Novocastra, USA) and MUC2 (Lyophilized Mouse monoclonal antibody; NCL-MUC-2, dilution 1/150, Novocastra, USA), for 120 minutes. Sections were washed three times for 5 minutes in PBS and incubated with secondary antibody, Labvision Value primary antibody enhancer (Ref: TL-125-PBS) for 15 minutes. After slides were washed three times in PBS, Labvision value HRP polymer (Ref: TL-125 PHS) was used. The chromogen was AEC (Life Science Division Liquid AEC Substrate kit; Catalog no C01-12). Sections were rinsed in tap water, counterstained with hematoxylin and mounted with cover-slips.

Evaluation of immunohistochemistry: The staining properties were examined by one pathologist (ICT) and consulted by an experienced GI pathologist (GBD) for any difference in the areas of IM, NGCE, DCE and SE in 59 cases. Cytoplasmic staining was considered as positive for COX2 and MUC2 while positive nuclear staining was searched for CDX2. The number of positive cells were assessed by eyeballing and immunohistochemistry scored semiquantitavely, as 0 , if there was no staining; +1 , if there was positive staining in less than $30 \%$ of the cells; +2 , if positive in $31-60 \%$ of the cells; and +3 , if more than $60 \%$ cells were positive.

Statistical analysis: The results were evaluated by frequency analysis as numbers and percentages and compared with Pearson and Fisher exact tests statistically in SPSS 8,0 for windows and p values of $<0.05$ were considered as significant. The statistical analysis of the immunohistochemistry results were initially made according to semiquantitative positivity scores of staining extensiveness, as $0-+3$. However as the number of cases were small in each group, final statistical correlation was searched between negative and all the positive groups, regardless of their staining score.

\section{RESULTS}

Patient profile: The cases having the diagnosis of $\mathrm{BE}$ in the last 2 years, had a mean age of 49.8 , and a median age of 48 . The age interval was $28-79$, and male/female ratio was $4 / 1$. The age distribution did not show significant difference in the cases those were positive for dysplasia (22 cases) from the ones who had no dysplasia $(\mathrm{p}=0.87)$.

Immunohistochemistry results: The distribution of the staining was examined at the areas of IM as well as at NGCE, and DCE in comparison with the mucosa having IM.

The number of cases with CDX2, COX2 and MUC2 positivity in the IM was higher than the ones in NGCE and DCE. The IM areas were CDX2 positive in $76.3 \%$ of the cases, the DCE areas were only positive in $1,7 \%$ and the NGCE in $23.7 \%$ of the cases (Figure 1 ). The CDX2 positivity in IM was correlated with positivity in NGCE so that IM areas were CDX2 positive when NGCE areas were positive in the same cases, and this difference was statistically significant $(\mathrm{p}=0.001)$. Similar correlation was also found between NGCE and DCE areas $(\mathrm{p}=0.005)$ (Table I).

COX2 was positive in IM areas in $93.2 \%$ of the cases while it was $8 \%$ in DCE. In NGCE, the positivity was between these two with a percentage of $47.5 \%$ (Figure 2). These results were statistically significant $(\mathrm{p}=0.034)$.

MUC2 positivity was seen in IM areas in $93.2 \%$ of cases,

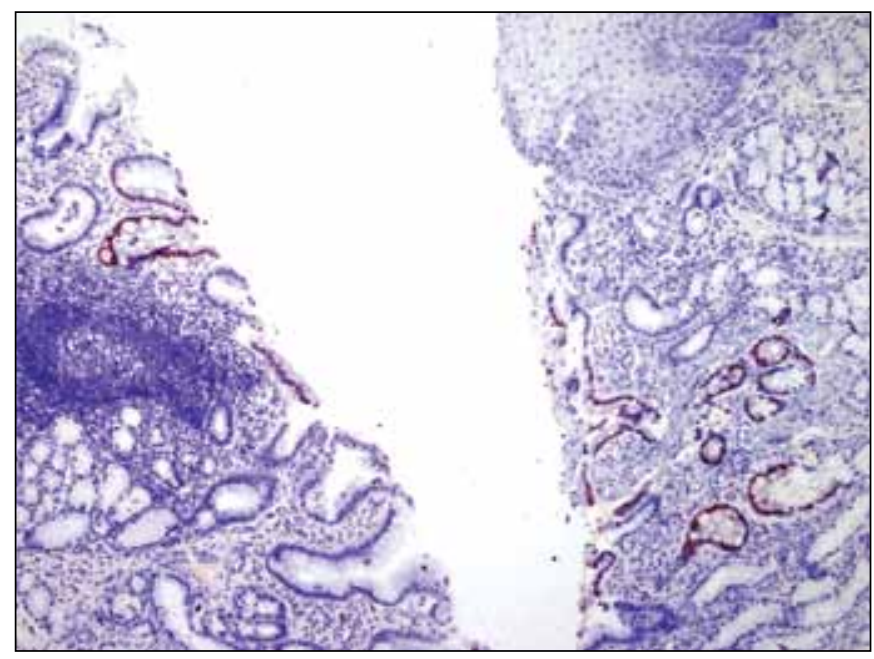

Figure 1: CDX2 positivity in intestinal metaplasia and non-goblet columnar epithelium (x200). 
$4 \%$ of cases in DCE areas, in $11.9 \%$ of cases in the NGCE (Figure 3).

The expression of COX2 in IM was significantly correlated with the expression of CDX2 and MUC2 in IM areas ( $\mathrm{p}=0.002$ and $\mathrm{p}=0.0001$, respectively).

Control group: There was no positive staining in the control group which included biopsies of esophagus. Findings were also similar in the gastric mucosa samples present in the biopsies. Strong positivity of all the 3 antibodies was observed in the duodenal mucosae present in the biopsies.

Staining in squamous epithelium: Adjacent SE seen in 54 of the cases was not stained by CDX2 and MUC2. However, we detected a faint COX2 positivity compared to IM, in SE in $34 / 54(62.9 \%)$ of the cases (Figure 2). COX2 positivity in SE was correlated with the CDX2 and MUC2 positivity in IM, and the correlation was statistically significant $(\mathrm{p}=$ 0.023 and 0.026 , respectively).

Results in the presence of dysplasia: At initial examination, dysplasia was noted in 10 cases however after immunohistochemistry, re-evaluation of cases revealed additional 12 cases with foci of low grade dysplasia areas. Finally, a total of 22 cases (\%37.3) were identified with either low or high grade dysplasia. The distribution of the patients according to dysplasia grades are presented in Table II. The expression of the markers in those dysplastic cases are given in Table

Table I: Immunohistochemical results in different mucosal areas

\begin{tabular}{|c|c|c|c|c|c|c|}
\hline & \multirow[b]{2}{*}{ Mucosa } & \multicolumn{4}{|c|}{ Extent of staining* } & \multirow[b]{2}{*}{ Total positive cases } \\
\hline & & $\begin{array}{c}0 \\
\text { n (\%) }\end{array}$ & $\begin{array}{c}+1 \\
\mathrm{n}(\%)\end{array}$ & $\begin{array}{c}+2 \\
\mathrm{n}(\%)\end{array}$ & $\begin{array}{c}+3 \\
\text { n (\%) }\end{array}$ & \\
\hline \multirow{3}{*}{$\mathrm{CDX} 2$} & IM & $14(23.8 \%)$ & $18(30.5 \%)$ & $17(28.8 \%)$ & $10(16.9 \%)$ & $45(76.2 \%)$ \\
\hline & NGCE & $45(76.3 \%)$ & $10(16.9 \%)$ & $4(6.8 \%)$ & 0 & $14(23.7 \%)$ \\
\hline & $\mathrm{DCE}^{* *}$ & $50(97.3 \%)$ & $1(1.7 \%)$ & 0 & 0 & $1(1.7 \%)$ \\
\hline \multirow{3}{*}{ COX2 } & $\mathrm{IM}$ & $4(6.8 \%)$ & $7(11.9 \%)$ & $15(25.4 \%)$ & $33(55.9 \%)$ & $55(93.2 \%)$ \\
\hline & NGCE & $31(52.5 \%)$ & $26(44.1 \%)$ & $2(3.4 \%)$ & 0 & $28(47.5 \%)$ \\
\hline & $\mathrm{DCE}^{\star *}$ & $47(92 \%)$ & $4(8 \%)$ & 0 & 0 & $4(8 \%)$ \\
\hline \multirow{3}{*}{ MUC2 } & IM & $4(6.8 \%)$ & $8(13.6 \%)$ & $12(20.3 \%)$ & $35(59.3 \%)$ & $55(93.2 \%)$ \\
\hline & NGCE & $52(88.1 \%)$ & $6(10.2 \%)$ & $1(1.7 \%)$ & 0 & $7(11.9 \%)$ \\
\hline & $\mathrm{DCE}^{* *}$ & $49(96 \%)$ & $2(4 \%)$ & 0 & 0 & $2(4 \%)$ \\
\hline
\end{tabular}

IM: Intestinal metaplasia, NGCE: Non-goblet columnar epithelium, DCE: Distant columnar epithelium.

${ }^{\star} \mathbf{0}$ : no staining, 1: staining in 1-30\%, 2: staining in 31-60\%, 3: staining in $>60 \%$ of cells.

${ }^{*}$ There is no DCE in 8 of the cases.

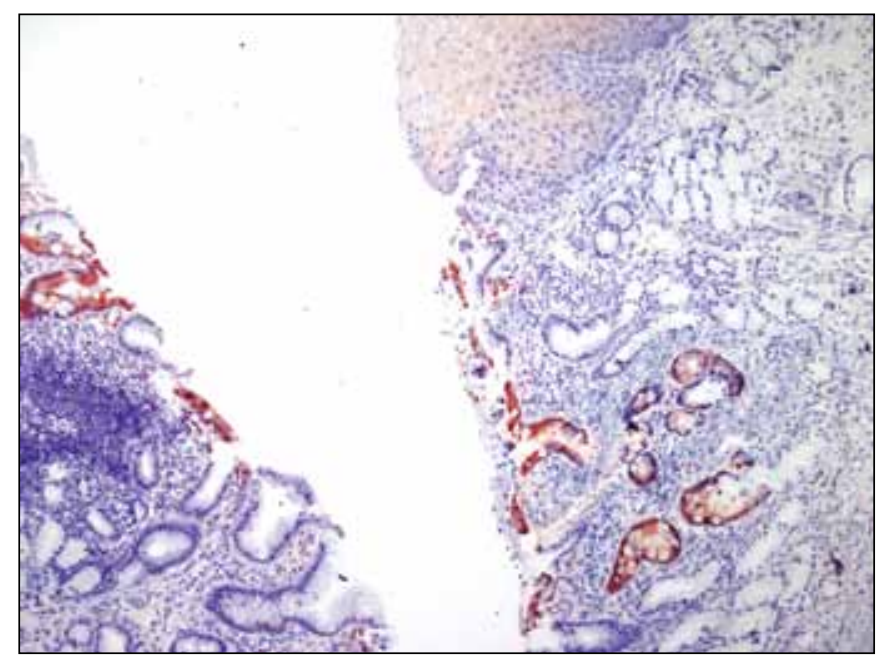

Figure 2: COX2 positivity in intestinal metaplasia and non-goblet columnar epithelium. Note the faint cytoplasmic staining in squamous epithelium (x200).

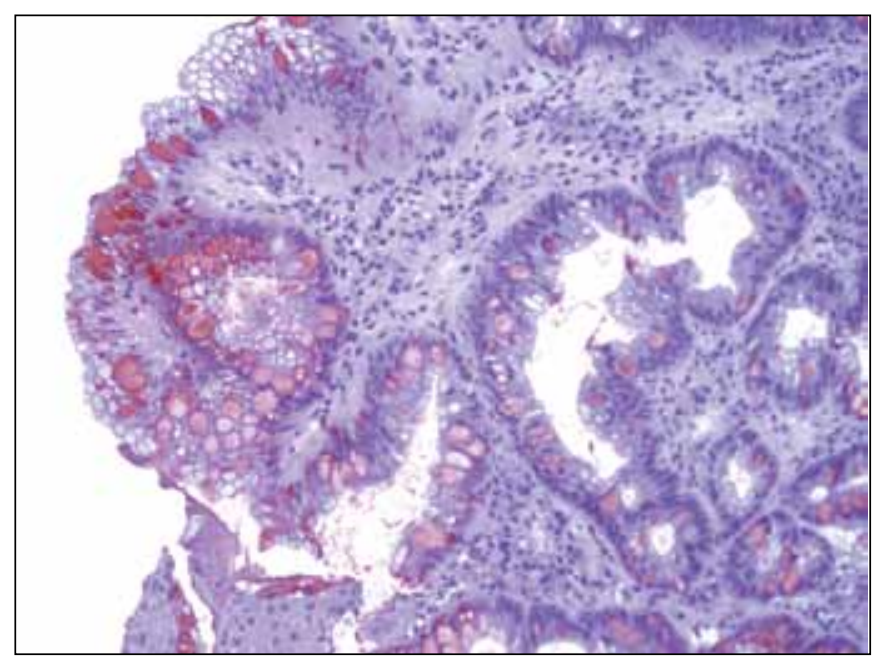

Figure 3: MUC2 expression at the site of intestinal metaplasia and non-goblet columnar epithelium (x200). 
III. In the presence of dysplasia the expression of all the 3 markers were significantly decreased $(\mathrm{p}=0.0001)$. The percentage of cases with CDX2 expression was $18.2 \%$ (4/22), with COX2 expression was $27.3 \%(6 / 22)$, and with MUC2 expression was $31.9 \%$ (7/22). Similarly, the expression of the markers decreased in IM areas with the presence of dysplasia and the results were statistically significant $(\mathrm{p}=0.039$, $0.0001,0.0001$, respectively).

In re-evaluation of dysplasia after immunohistochemistry, we realized that the cases those were reclassified as "having dysplasia" showed decreased MUC2 expression at IM areas (Figure 4).

COX2 expression was already observed in SE, however with the presence of dysplasia, we noted decreased expression of COX2 in the adjacent SE; so that the ratio of positive cases was $56.2 \%(9 / 16)$ in the presence of dysplasia, while it was $85.7 \%(24 / 28)$ in the dysplasia negative group and the results were statistically significant $(\mathrm{p}=0.014)$.

\section{DISCUSSION}

The mean age of $\mathrm{BE}$ in the previous studies was in a range of $61-67$, and there was a male predominance $(12,16,17)$. The mean age of our study group was 49.8 years, with a median age of 48 years. The age interval was $28-79$, and male/female ratio was $4 / 1$. These demographic findings were similar to the literature with a slight lower mean age in our group probably because of the younger population structure of our country. Our study group did not show a difference in the dysplastic-non dysplastic group ( $\mathrm{p}=0.87)$, although

Table II: The distribution of cases according to the presence of dysplasia

\begin{tabular}{|l|c|}
\cline { 2 - 2 } \multicolumn{1}{c|}{} & Number of cases $\mathbf{n}(\%)$ \\
\hline Negative for dysplasia & $37(62.7)$ \\
\hline Low grade dysplasia & $13(22)$ \\
\hline High grade dysplasia & $9(15.3)$ \\
\hline Total & $59(100)$ \\
\hline
\end{tabular}

Chinyama et al. states a 10 years older age in the dysplasia positive group (9).

$\mathrm{BE}$ is a risk factor for adenocarcinoma and understanding of the early molecular events involved in the pathogenesis might create probability for translational researches to prevent EA. CDX2 expression has been found in inflamed esophageal SE but not in normal SE $(4,11,16,18)$. The precise molecular events mediating the transformation of SE into BE are not well understood, but several studies suggest key roles of certain developmental pathways, and HOX genes, which encode for transcription factors those regulate the intestinal differentiation $(4,7,16)$. The intestinal differentiation in embryo is achieved by the expression of CDXs $(4,7)$. Metaplastic conditions like BE are associated with a high cell turnover that may be induced by chronic inflammation. Metaplasia occurs when such changes affect homeotic genes like CDXs, that control transformation to a tissue type that was present during embryological development. This will explain the case in the esophagus as it is initially lined by columnar epithelium in human embryo (4).

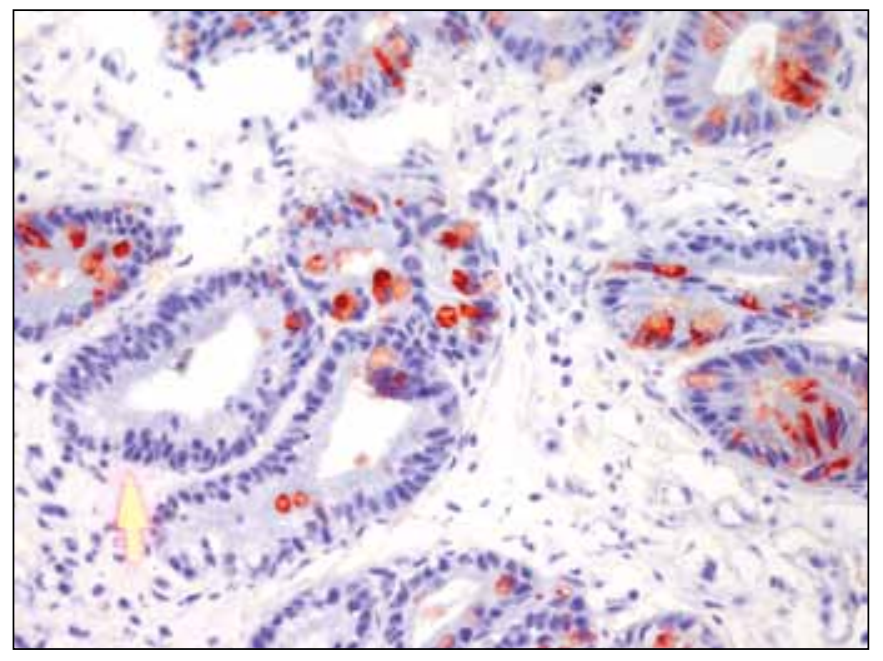

Figure 4: Decreased MUC2 expression at the site of dysplasia (arrow), in comparison to the adjacent epithelium (x200).

Table III: The staining properties at the sites of dysplasia

\begin{tabular}{|c|c|c|c|c|c|}
\hline & \multicolumn{5}{|c|}{ Extent of staining ${ }^{\star}$} \\
\hline & $\begin{array}{c}0 \\
\text { n (\%) }\end{array}$ & $\begin{array}{c}+1 \\
\text { n }(\%)\end{array}$ & $\begin{array}{c}+2 \\
n(\%)\end{array}$ & $\begin{array}{c}+3 \\
\text { n }(\%)\end{array}$ & $\begin{array}{l}\text { Total positive cases } \\
(\mathbf{n} / 22)(\%)\end{array}$ \\
\hline CDX2 & $18(81.8 \%)$ & $3(13.6 \%)$ & $1(4.6 \%)$ & 0 & $4 / 22(18.2 \%)$ \\
\hline COX2 & $16(72.7 \%)$ & $4(18.1 \%)$ & $1(4.6 \%)$ & $1(4.6 \%)$ & $6 / 22(27.3 \%)$ \\
\hline MUC2 & $15(68.1 \%)$ & $7(31.9 \%)$ & 0 & 0 & $7 / 22(31.9 \%)$ \\
\hline
\end{tabular}

${ }^{*} \mathbf{0}$ : no staining, $+\mathbf{1}$ : staining in 1-30\%, +2 : staining in $31-60 \%,+3$ : staining in $>60 \%$ of cells. 
In studies of esophageal biopsy specimens taken from patients with $\mathrm{BE}, \mathrm{CDX} 2$ expression levels are higher in $\mathrm{BE}$ than in normal esophageal SE, in which the levels are almost undetectable (4-6). Using immunohistochemistry, CDX2 has been demonstrated in non-dysplastic BE, BE with dysplasia, and EA (4). Moreover CDX2 expression can be found in inflamed esophageal SE before intestinal markers like MUC2, sucrase isomaltase, defensin- 5 can be detected. This finding suggests that CDX2 activation is an early event in formation of $\mathrm{BE}(4,11,16,18)$.

Groisman et al. conclude that CDX2 is a highly sensitive marker of IM in BE (100\% expression in GCs where it is expressed in a significant minority of cases (38\% of cases) in NGCE, suggesting that it may detect intestinal phenotypic modifications in the absence of goblet cells (6). In our study group, IM areas were CDX2 positive in $76.3 \%$ of the cases. In NGCE CDX2 positivity was seen in $23.7 \%$ of cases which was higher than the DCE areas in which CDX2 positivity was seen in only $1.7 \%$ of the cases. Similarly, MUC2 positivity was observed in $93.2 \%$ of cases with IM and $11.9 \%$ of NGCE areas which was already almost three times more frequent than DCE. There are several studies searching the CDX2 and MUC2 expression in BE; in one of them Steininger et al. observed MUC2 expression only in definite BE with at the same time, a nuclear CDX2 positivity, and concluded that early BE is MUC2 negative (12). Chaves et al. evaluated mucin subtypes in IM or NGCE and carcinoma, and showed $72.7 \%$ MUC2 positivity in mucosae with IM and none of NGCE (18). Hahn Hejin et al. have studied CDX2 and MUC2 expression in BE, NGCE and IM (16). In their study, IM was MUC2 and CDX2 positive in $85 \%$ and $98 \%$ of the cases respectively, while in NGCE, MUC2 expression was not seen but CDX2 expression ratio was $43 \%$.

The results all support that MUC2 positivity is unique to the goblet cells in BE. But as observed in our study CDX2 expression is different in DCE and NGCE adjacent to GCs. This observation may also serve as an additional support to the hypothesis that background non-goblet columnar epithelium shows physiologic properties of 'intestinal' differentiation. In contrast to Hahn Hejin et al. and Groisman et al. $(6,16)$; who have not found statistically significant difference, our results were statistically significant and CDX2 expression seems to be an early modification in sequence of BE. In our study group, NGCE were MUC2 positive in $11.9 \%$ (7/59), while CDX2 positivity was $23.7 \%$ $(14 / 59)$ in accordance with those earlier studies $(6,16,18)$. Steininger et al. (12) hypothesize that IM is proceeded by early Barrett mucosa (multilayered and ciliated epithelium), and has granular cytoplasmic and/or focal nuclear CDX2 positivity, in contrast to Groisman et al (6) who does not regard cytoplasmic staining as positive however we found cytoplasmic CDX2 positivity in $38.9 \%$ of the cases besides nuclear staining. However this cytoplasmic positivity did not show a statistically significant relationship neither with the presence of $\mathrm{BE}$ nor dysplasia, nor with the staining of other markers.

Chinyama et al. demonstrated aberrant expression of MUC2 in GCs of BE and its loss when the epithelium becomes dysplastic (9). Philips et al. showed CDX2 positivity as a sensitive marker of IM in BE, and its loss primarily in highgrade dysplasia and adenocarcinoma (5). Villanacci et al. in accordance with them, has found decreased expression of CDX2 from BE (71.6\%) to low grade dysplasia (35.3\%) and high grade dysplasia (17.14\%) (17). In contrast, only Weimann et al. have reported increased CDX2 expression in the sequence of BE-dysplasia (19). In our study, we observed decreased CDX2 and MUC2 expression in the presence of dysplasia (18.2\% and $31.9 \%$ respectively). This finding may be useful in examining the presence of dysplasia in difficult cases. As we re-examined our cases having decreased MUC2 expression, for the presence of dysplasia, 12 of the cases were reclassified in the dysplastic group although they were reported to be negative for dysplasia before. However, this finding is not verified in other studies; such that in one, searching the pattern of MUC expression associated with the development and progression of dysplasia in $\mathrm{BE}$, results showed no significant difference of MUC staining in BE with or without dysplasia. Alterations in MUC expression occur in the progression of dysplasia in BE. However, none of these markers help to identify a subgroup of patients at increased risk for neoplasia (20). It is not possible to predict this outcome either in the present study, as our series doesn't include carcinomas. However long-term follow-up of our patients would give more promoting results in this aspect.

COX2 is not expressed in normal (non-inflamed) gastrointestinal epithelium but is expressed in esophagitis, $\mathrm{BE}$ and intestinal metaplasia of the stomach and increases from metaplasias to cancer (7). Song et al. showed that unconjugated dihydroxy bile acids were potent stimulators of COX2 induction in BE and EA cells (15). Similarly, several studies concluded that the increase in COX2 results in increased cell proliferation, IM, dysplasia and EA $(13,14)$. Besides these, Möbius et al. have found increased COX2 expression in relation with increased Ki-67 score, increased neovascularization and decreased survival in EA patient (21). Majka et al. (22) reported increased COX2 expression in $\mathrm{BE}$, and state that the expression is in parallel with the degree of dysplasia, although Villanacci et al. (17) 
have not found any significant difference. We found COX2 expression in $93.2 \%$ of the IM areas, $8 \%$ of the DCE areas, and in $47.5 \%$ of non-goblet CM. The expression of COX2 in IM was parallel to the expression of CDX2 and MUC2 in IM areas ( $\mathrm{p}=0.023$ and 0.026 , respectively).

As our study group does not include patients having carcinoma, although we found decreased expression of COX2 in dysplasia (27.3\%), our results may not reflect the changes in carcinoma.

In our study group COX2 expression was seen in $75.5 \%$ $(34 / 45)$ of the SE adjacent to BE. There was no staining in the control group which has no BE. In the presence of dysplasia, we observed decreased expression of COX2 in the adjacent SE and the NGCE (56.2\% versus $85.7 \%$ and $40.9 \%$ versus $59.4 \%$ respectively). Such a difference has not been shown in the previous studies. Only Brabender et al. report expression in normal SE of adenocarcinoma, while dysplasia was not searched (13).

\section{CONCLUSION}

The expression of CDX2, COX2 and MUC2, which are markers of intestinal differentiation, is seen in esophagus, in cases of BE. Our study in addition to confirming these observations also showed decreased expression of CDX2 and MUC2 in columnar epithelium in the case of dysplasia. To speculate the hypothesis that decreased expression of COX2 in adjacent SE could be helpful in confirming the presence of dysplasia even if the biopsy doesn't include Barrett mucosa, prospective studies are necessary to determine the clinical value of this approach.

\section{ACKNOWLEDGMENTS}

We want to thank Gülçin Civan, Reyhan Yaşar, Pınar Korkmaz and Ozan Aydoğmuş for their great support for this study.

\section{REFERENCES}

1. Fenoglio C: Gastrointestinal Pathology, an atlas and text. 3rd ed., Philadelphia, Lippincott Wilkins, 2008, 62-68

2. Odze RD: Update on the diagnosis and treatment of Barrett esophagus and related neoplastic precursor lesions. Arch Pathol Lab Med 2008, 132:1577-1585

3. Riddell RH, Odze RD: Definition of Barrett's esophagus: time for a rethink- Is intestinal metaplasia dead? Am J Gastroenterol 2009, 104:2588-2594

4. Souza RF, Krishnan K, Spechler SJ: Acid, Bile, and CDX: the ABCs of making Barrett's metaplasia. Am J Physiol Gastrointest Liver Physiol 2008, 295:G211-G218

5. Phillips RW, Frierson HF Jr, Moskaluk CA: Cdx2 as a marker of epithelial intestinal differentiation in the esophagus. Am J Surg Pathol 2003, 27:1442-1447
6. Groisman GM, Amar M, Meir A: Expression of the intestinal marker $\mathrm{Cdx} 2$ in the columnar-lined esophagus with and without intestinal (Barrett's) metaplasia. Mod Pathol 2004,17:1282-1288

7. Colleypriest BJ, Palmer RM, Ward SG, Tosh D: Cdx genes, inflammation and the pathogenesis of Barrett's metaplasia. Trends in Molecular Medicine 2009,15:313-322

8. Burjonrappa SC, Reddimasu S, Nawaz Z Gao X, Sharma $P$, Loggie B: Mucin expression profile in Barrett's, dysplasia, adenocarcinoma sequence in the esophagus. Indian J Cancer 2007, 44:1-5

9. Chinyama CN, Marshall RE, Owen WJ, Mason RC, Kothari D, Wilkinson ML, Sanderson JD: Expression of MUC1 and MUC2 mucin gene products in Barrett's metaplasia, dysplasia and adenocarcinoma: an immunopathological study with clinical correlation. Histopathology 1999, 35:517-524

10. Van De Bovenkamp JH, Korteland-Van Male AM, Warson C, Büller HA, Einerhand AW, Ectors NL, Dekker J: Gastric-type mucin and TFF-peptide expression in Barrett's oesophagus is disturbed during increased expression of MUC2. Histopathology 2003, 42:555-565

11. Hu Y, Jones C, Gellersen O, Williams VA, Watson TJ, Peters JH: Pathogenesis of Barrett esophagus deoxycholic acid up-regulates goblet-specific gene MUC2 in concert with CDX2 in human esophageal cells. Arch of Surg 2007, 142:540-545

12. Steininger H, Pfofe DA, Müller H, Haag-Sunjic G, Fratianu V: Expression of CDX2 and MUC2 in Barrett's mucosa. Pathol Res Pract 2005, 201:573-577

13. Brabender J, Marjoram P, Lord RV, Metzger R, Salonga D, Vallböhmer D, Schäfer H, Danenberg KD, Danenberg PV, Selaru FM, Baldus SE, Hölscher AH, Meltzer SJ, Schneider PM: The molecular signature of normal squamous esophageal epithelium identifies the presence of a field effect and can discriminate between patients with Barrett's esophagus and patients with Barrett's-associated adenocarcinoma. Cancer Epidemiol Biomarkers Prev 2005, 14:2113-2117

14. Si J, Fu X, Behar J, Wands J, Beer DG, Souza RF, Spechler SJ, Lambeth D, Cao W: NADPH oxidase NOX5-S mediates acidinduced cyclooxygenase-2 expression via activation of NF-kappa B in Barrett's esophageal adenocarcinoma cells. Biol Chem 2007, 282:16244-16255

15. Song S, Guha S, Liu K, Buttar NS, Bresalier RS: COX-2 induction by unconjugated bile acids involves reactive oxygen species-mediated signalling pathways in Barrett's oesophagus and oesophageal adenocarcinoma. Gut 2007, 56:1512-1521

16. Hahn HP, Blount PL, Ayub K, Das KM, Souza R, Spechler S, Odze RD: Intestinal differentiation in metaplastic, nongoblet columnar epithelium in the esophagus. Am J Surg Pathol 2009, 33:1006-1015

17. Villanacci V, Rossi E, Zambelli C, Galletti A, Cestari R, Missale G, Casa DD, Bassotti G: COX-2, CDX2, and CDC2 immunohistochemical assessment for dysplasia-carcinoma progression in Barrett's esophagus. Dig Liver Dis 2007, 39:305311

18. Chaves P, Cruz C, Dias Pereira A, Suspiro A, de Almeida JC, Leitão CN, Soares J: Gastric and intestinal differentiation in Barrett's metaplasia and associated adenocarcinoma. Dis Esophagus 2005, 18:383-387 
19. Weimann A, Zimmermann M, Gross M, Slevogt H, Rieger A, Morawietz L: CDX2 an LI-Cadherin expression in esophageal mucosa: Use of both markers can facilitate the histologic diagnosis of Barrett's Esophagus and carcinoma. Int J Surg Pathol 2010, 18:330-337

20. Glickman JN, Blount PL, Sanchez CA, Cowan DS, Wongsurawat VJ, Reid BJ, Odze RD: Mucin core polypeptide expression in the progression of neoplasia in Barrett's esophagus. Hum Pathol 2006, 37:1304-1315
21. Möbius C, Stein HJ, Spiess C, Becker I, Feith M, Theisen J, Gais P, Jütting U, Siewert JR: COX2 expression, angiogenesis, proliferation and survival in Barrett's cancer. Eur J Surg Oncol 2005, 31:755-759

22. Majka J, Rembiasz K, Migaczewski M, Budzynski A, PtakBelowska A, Pabianczyk R, Urbanczyk K, Zub-Pokrowiecka A, Matlok M, Brzozowski T: Cyclooxygenase-2 (COX2) is the key event in pathophysiology of Barrett's esophagus, lesson from experimental animal model and human subjects. J Physiol Pharmacol 2010, 61:409-418 